\title{
Effectiveness of Aloe Vera and Lemon Juices Concentration in Reducing Formalin Content in Tofu Sumedang
}

\author{
C. Daniela*, H. Rusmarilin* and H. Sinaga \\ Department of Food Science, Faculty of Agriculture, University of Sumatera Utara, \\ Medan, Indonesia \\ *Corresponding author
}

\section{A B S T R A C T}

This study aims to determine effects of concentration and immersion duration of aloe vera and lemon juices in reducing formalin in the tofu soaked with the $5 \%$ formalin. This

\section{Keywords}

Aloe vera juices, Formalin, Lemon juices, Tofu

Article Info

Accepted:

10 March 2018

Available Online:

10 April 2018 research was experimentally conducted by two Completely Randomized Designs. Firstly, the factorial design with two factors comprising the concentration comparison of aloe vera and lemon juices at 100\%:0\%, 80\%:20\%, 60\%:40\%, 40\%:60\%, 20\%:80\%, 0\%:100\% and immersion time for 30, 60, and 90 minutes was employed. Secondly, the non-factorial design was treated during $0,3,6$, and 9 days. The sample possessing the highest potential in decreasing formalin was tested regarding storage period. The result showed that the ratio of aloe vera and lemon juices and immersion time had the significant effects on formalin content, protein content, and total microbe. The formalin level, protein content, and total microbe soaked in the $5 \%$ formalin resulted in respectively $84.214 \mathrm{mg} / \mathrm{kg}, 3.8 \%$, and $0.000 \log \mathrm{CFU} / \mathrm{ml}$. The best treatment in reducing formalin was the $100 \%$ aloe vera juice with the 90-minute immersion. The sample was subsequently stored for 3, 6, and 9 days. The longer the storage was, the more microbes increased. Aloe vera juice was more effective in reducing the formalin content than lemon juice.

\section{Introduction}

Tofu is one of the soy products which are in great demand by the countries in Asia, especially Indonesia. Nutritionally, tofu is cholesterol free with low saturated fat, and high protein. As a calcium-rich food, tofu contains $50 \%$ protein. Regular consumption of the soy products reduces the risk of cronic illnesses such as cancer, heart disease, and stroke (Jooyandeh, 2011). On the other hand, tofu is classified as perishable food with a limited short shelf life. Consequently, in producing tofu manufacturers often add preservative such as formalin in order to avoid major losses. Formalin is one of preservative specimens officially prohibited in preserving foodstuffs in accordance with the regulation of Health Minister of the Republic of Indonesia No. 033 of 2012 on food additives (Matondang, et al., 2015).

Formalin is a reactive compound which can bind to compounds of foodstuffs, such as proteins, fats, and carbohydrates. The mechanism of formalin as a preservative 
occurs when formaldehyde reacts with proteins to form sequences between adjacent proteins. As a result of these reactions, the protein hardens and is insoluble (Shita, 2016). The indigestible protein will be a foreign substance (antigen) in the body affecting immune response (Brody, 1994). In the preservation of white shrimp, it has been proven that the use of formalin affects the nutritional value of dietary proteins (amino acids and PER) and damages the organs of experimental animals (Wikanta, 2011).

In addition, formalin is also a source of reactive oxygen (SOR) and exogenous free radicals. Formaldehyde exposure leads to increase reactivity of SOR that will damage DNA, protein and lipid cell membrane composers (Mahdi et al., 2008). SOD, vitamin $\mathrm{E}$, and vitamin $\mathrm{C}$ have potential in terms of capturing reactive oxygen compounds in normal reproductive tracts. Based on the reports of extraordinary events received by POM in 2016, 6,136 people were exposed to the food poisoning due to the excessive formalin content which led to 3,413 sick people and 8 died people (FDSA, 2017).

Thus, it can be said that the formalined food is a threat to health of people's lives both in the short and long term. Accordingly, endeavors are required to gain food sources that should be free of formalin. In an attempt to acquire the formalin-free food, the use of natural ingredients such as aloe vera and lemon which are very easy to find in Indonesia can be a solute alternate.

Saponin compounds contained in aloe vera potentially can decrease the amounts of formaldehyde in involvement with the technique of immersion. With the way of immersing, antibacterial compounds which are considered harmless if consumed by human beings. The process which involves saponin in aloe vera gel causing reduction of the formalin level is known as saponification reaction (soap forming process) where in the soap is included to the surfactant group (Gusviputri, 2013). Based on the previous research, Jannah, et al., (2014) found that galangal (Alpinia galanga) at the $20 \%$ concentration with 60 minutes of soaking time reduced the formalin level to $64 \%$ in white shrimp.

Citric acid is used as an environmentally friendly cleaning agent. The antioxidant activity of lemon samples (Citrus Limon L) reported by Ali, et al., 2010 demonstrated that the presence of antioxidant found in lemon was one of the factors supporting the decrease of formalin content in the formalined tofu.

With respect to some previous research showing the effectiveness of saponin and citric acid in reducing formalin level, this research aims to find out the influence of the comparison of aloe vera and lemon juices in reducing formalin level and its impact to the shelf life of tofu.

\section{Materials and Methods}

\section{Equipment and material}

The equipments used in this study were analytical flask Kjedahl $100 \mathrm{ml}$, distillation equipment (Gerhard), burette (Pyrex ${ }^{\circledR}$ IWAKI TE-32), Erlenmeyer $100 \mathrm{ml}$, volumetric flask $100 \mathrm{ml}$, pipette volume $10 \mathrm{ml}$, analytical scales (Denver Instrumen), sterile cup, and HPLC (Shimadzu).

In this research, materials utilized were soybeans, aloe vera, lemon, and chemical substances. Aloe vera type Barbadensis Miller. Soybeans were purchased from the local market. Aloe vera leaves with the type of Barbadensis miller were gained from Sunggal Street, Baru 2 Alley No. 16, Medan Sunggal. Middle Eastern lemons were selected and acquired from a lemon plantation on Bunga 
Sedap Malam Street IX No. 1A, Sempakata, Medan Selayang. The chemical substances used were $\mathrm{H}_{2} \mathrm{SO}_{4}$ (Merck), $\mathrm{NaOH} 50 \%$ (Merck), boric acid (Merck), methyl red indicator (Merck), HCL (Merck), aquadest, formaldehyde $\quad 37 \% \quad$ (Merck), dinitrofenilhidrazin $0.1 \%$, dichloromethane (Merck), methanol (smart lab), plate count agar (oxoid).

\section{Experimental method}

\section{Experimental design}

This research employed experimental design approaches involving completely randomized factorial design and completely randomized nonfactorial design. The conduct of the completely randomized designs comprised two factors. The first factor which dealt with the comparison of the juices of aloe vera and lemon was grouped by 6 levels, incorporating 100:0, 80:20, 60:40, 40:60, 20:80, and 0:100 (\%). The second factor related to duration of soaking was divided into 3 levels, embracing 30, 60, and 90 minutes. The nonfactorial experimental approach with the completely randomized design was concerned to the duration of storage $0,3,6$, and 9 days. Each treatment was conducted three times.

\section{Experimental procedure}

In this research, the experimental procedure was carried out in two steps. The first step was composed of preparation of tofu simulation, the making of the $5 \%$ formaldehyde solution, and the aloe vera and lemon juice making. The analysis of the level of formalin, protein content, and the total of microbes to the controlled tofu, the formalined tofu, and the tofu which had been treated against the ration of juices concentration and the immersion duration. In the second step, the selection of the best treatment which could lower the greatest formaldehyde solution was utilized and the sample undergoing the highest formalin decrease percentage was continued for the treatment of storage period.

\section{Preparation of making tofu}

Disortation of soybeans was done firstly, then washed, and soaked lastly in the clean water during 12 hours. The soybeans were smashed by using blender, added by warm water with ratio 1:2 between the warm water and soybeans and then filtered. The obtained filtrate was heated, stirred, and added acetat acid up to the form of tofu lumps. The lumps were ultimately solidified to form tofu which was used as a sample of the research.

\section{The making of aloe vera and lemon juice}

The making of aloe vera juice was started by washing a few leaves of Barbadensis miller aloe vera. After washed, the yellow layers just beneath the rind of the leaves were peeled off and the layers were discarded. Once all the rind and yellow layers had been removed, there should be left some clear aloe vera gel which was subsequently blanched, blundered.

All the juice out of the aloe vera gel was eventually filtered. The making of lemon juice was done firstly by cutting lemons in half, squeezed them, and filtered the juice to attain pure essence from each of half. The obtained juices of aloe vera and lemon were adjusted according to the desired percentage and then weighed on the basis of the ratio of aloe vera and lemon juice in this study including 100 , $80,60,40,20$, and $0(\%)$.

\section{The soaking of tofu with Aloe vera and lemon juice}

The formalined tofu was soaked into the mixture of aloe vera and lemon juices with the ratio respectively 100\%:0\% (A1) 80\%:20\% (A2), 60\%:40\% (A3), 40\%:60\% (A4), 
20\%:80\% (A5) 0\%:100\% (A6), which was then soaked for 30 (L1), 60 (L2), and 90 (L3) (minutes). Each treatment was carried out to investigate the formalin content, protein content, and total microbes.

The best treatment was obtained by observing the largest percentage of thr decrease of formalin content and the highest percentage of protein content. Additionally, the treatment of storage duration was continued to determine the effect of immersion of aloe vera with lemon juice at tofu shelf life. Tofu would be stored in cold storage during 0 (M1), 3 (M2), 6 (M3), and 9 (M4) days and then the total of microbes in the tofu would be analyzed.

Afterward, sample was stored in the refrigerator with temperature at $10^{\circ} \mathrm{C}$ during 0 , 3, 6, and 9 days. After storage period, the sample was eventually was analysed in associated to the total of microbes.

\section{HPLC analysis for formaldehyde determination}

The modified protocol to detect formaldehyde in tofu by HPLC instrument (Model SPD-M20 A) was conducted based on the method described by Li, et al., (2007) and validated HPLC method by Wahed et al., (2016) as follows:

\section{Sample preparation}

Tofu was cut into dice and mashed using mortal and pestle. The sample was weighed as much as $\pm 5 \mathrm{~g}$ and $50 \mathrm{~mL}$ aqua demineralized (DM) was added and then heated at $96^{\circ} \mathrm{C}$ for 30 minutes. The sample was filtered using filter paper to obtain filtrate containing formaldehyde and then the filtrate was centrifuged at $3000 \mathrm{rpm}$ for 10 minutes and obtained a supernatant, then inserted into the vial and done degassing vial using the tool Branson 5200 Ultrasonic Cleaner.

\section{Formaldehyde derivatization}

The sample filtrate and standard solution (20 ppm, $60 \mathrm{ppm} 80 \mathrm{ppm}$, and $100 \mathrm{ppm}$ ) were taken from each as much $1 \mathrm{ml}$. A total of 0.5 $\mathrm{mL}$ of $0.1 \%$ DNPH solution was added, then extracted using dichloromethane. Furthermore, the phase of shaking was done and water was removed. Then, dichloromethane was evaporated and the evaporation residue was dissolved with $1 \mathrm{~mL}$ of methanol. The solution was then filtered using a $0.45 \mu \mathrm{m}$ membrane filter prior to injection. For each sample, two replicates were analyzed.

Results were expressed as $\mathrm{mg}$ of formaldehyde/L

\section{Analytical condition of HPLC}

HPLC used was HPLC Shimadzu type LC20AT/ SPD-20A, which consisted of a pump type LC-20AT, a column chamber type VPODS $(250 \times 4.6 \mathrm{~mm})$, VU-Vis detect SPD$20 \mathrm{~A}$. The sample volume was set at $20 \mu \mathrm{l}$ and the wavelength of the absorption detector was set at $355 \mathrm{~nm}$ and the oven temperature at $30^{\circ} \mathrm{C}$. Separation was achieved using isocratic elution with a mixture of water/methanol $(35: 65, \mathrm{v} / \mathrm{v})$. The total run time was 10 minutes. The peak areas were utilized for quantitative formaldehyde calculations.

\section{Determination of protein content}

The sample as much $0.5 \mathrm{~g}$ was fed into a Kjedahl flask, added $1.5 \mathrm{~g}$ selenium and $15 \mathrm{ml}$ of $\mathrm{H}_{2} \mathrm{SO}_{4}$, dissolved in an acid room to a clear solution, followed by heating for 1 hour, cooled, then diluted with aquadest in a measuring flask, and ultimately distilled by addition of $20 \mathrm{ml} \mathrm{NaOH} \mathrm{50 \% .} \mathrm{The} \mathrm{distillation}$ product was accommodated with $10 \mathrm{ml}$ boric acid and 3 drops of methyl red indicator. Distillation was carried out until the shelter 
reaches $100 \mathrm{ml}$. Thereafter, the distillation results were titrated with $0.02 \mathrm{~N} \mathrm{HCl}$ until a pink indicator was formed.

\section{Determination of the total microbe}

To test the number of microbes, using the calculated plate method or "pour plate" was assigned. The material was weighed $5 \mathrm{~g}$ and put into an Erlenmeyer flask containing $45 \mathrm{ml}$ of sterile physiological salt (dilution $10^{-1}$ ) and subsequently a series of dilutions were carried out with at least 5 diluting processes. The material was taken $1 \mathrm{ml}$ by using pipette from the last diluting process after 5 times dilution. Afterward, the material was put into a sterile petridish PCA media approximately $15 \mathrm{ml}$ was poured into the material. Allowing to be hardened, the material was wrapped with plastic wrap and then incubated for 48 hours at $37{ }^{\circ} \mathrm{C}$. With a period of 48 hours, the number of microbial colonies contained in the cup was counted under the condition of the number of colonies calculated between 30 and 300 .

\section{Results and Discussion}

The effect of the concentration of Aloe vera and lemon juice to quality parameter of tofu

The result of the research showed that the comparison of aloe vera and lemon juices contributed effects to the formalin level (\%), total of microbes $(\log \mathrm{CFU} / \mathrm{ml})$, and protein content (\%). The effects of comparison between aloe vera and lemon juices on the quality parameter of tofu can be seen in Table 1 while the effects of the immersion duration to the quality of tofu are shown in Table 2. In Table 3, it can be perceived the effects of storage duration on the total number of microbes in tofu. Table 1 reveals that the highest level of formalin was obtained in the treatment of A6 (0\%:100\%) at $65.161(\mathrm{mg} / \mathrm{kg})$ by performing the decrease of the formalin level at $22.63 \%$. In contrast, the lowest level of formalin was referred to the treatment of A1 (100\%:0\%) at $36.163(\mathrm{mg} / \mathrm{kg})$ with the potential of decreasing the formalin level at $57.05 \%$. The greater the percentage of aloe vera juice added, the greater the percentage decrease formalin (Fig. 1). The highest total microbe was attained in the treatment of the $100 \%$ aloe vera, which was 5.083 $(\log \mathrm{CFU} / \mathrm{ml})$, whereas the lowest content was at the $100 \%$ lemon juice treatment, which was 2.861 . The protein content of the $100 \%$ lemon juice protein resulted in the lowest protein content but the highest content was gained in the $100 \%$ aloe vera juice treatment.

Figure 2 reveals that the longer the immersion occurs, the lower the formalin content decreases. The 90-minute soaking can reduce the formalin content at $50.42 \%$ with the residual formalin at $41.752(\mathrm{mg} / \mathrm{kg})$. The highest total microbe derived in the L3 treatment (90 minutes) was 4.640 $(\log \mathrm{CFU} / \mathrm{ml})$, whereas the lowest total attained in the L1 treatment (130 minutes) was 3.978 $(\log C F U / m l)$. Table 3 shows the effect of storage duration on total microbial in tofu with each tested sample being know formalin, tofu control, and tofu sample which experienced the greatest decrease of formalin level. From each sample it was found that the longer the storage then the total microbial growing is increasing.

\section{Formalin content}

The A1 treatment with the $100 \%$ aloe vera juice was associated to the best treatment since it could decrease the greatest level of formalin. It demonstrates that the high percentage of aloe vera juice possessed the better ability in reducing the formalin content compared with the lemon juice due to the higher content of saponin in the aloe vera juice. 
Table.1 Effects of the concentration comparison of Aloe vera and lemon juice on parameter quality of tofu

\begin{tabular}{|l|c|c|c|}
\hline \multirow{2}{*}{\begin{tabular}{|c|c|} 
Treatment \\
Formalin \\
Content $(\%)$
\end{tabular}} & $\begin{array}{c}\text { Total Microbe }(\log \\
\text { CFU/ml) }\end{array}$ & $\begin{array}{c}\text { Protein Content } \\
(\%)\end{array}$ \\
\hline A1 & $36.163^{\mathrm{g}}$ & $5.083^{\mathrm{b}}$ & $5.541^{\mathrm{b}}$ \\
\hline A2 & $41.093^{\mathrm{f}}$ & $4.968^{\mathrm{b}}$ & $5.395^{\mathrm{c}}$ \\
\hline A3 & $46.499^{\mathrm{e}}$ & $4.858^{\mathrm{c}}$ & $5.232^{\mathrm{d}}$ \\
\hline A4 & $53.312^{\mathrm{d}}$ & $4.301^{\mathrm{d}}$ & $4.856^{\mathrm{e}}$ \\
\hline A5 & $57.976^{\mathrm{c}}$ & $4.170^{\mathrm{d}}$ & $4.530^{\mathrm{f}}$ \\
\hline A6 & $65.161^{\mathrm{b}}$ & $2.861^{\mathrm{e}}$ & $4.337^{\mathrm{g}}$ \\
\hline The Controlled Tofu & $0.000^{\mathrm{h}}$ & $5.552^{\mathrm{a}}$ & $6.331^{\mathrm{a}}$ \\
\hline The Formalined Tofu & $84.214^{\mathrm{a}}$ & $0.000^{\mathrm{f}}$ & $3.800^{\mathrm{h}}$ \\
\hline
\end{tabular}

A1-Aloe Vera Juice: Lemon Juice (100\%:0\%)

A2-Aloe Vera Juice: Lemon Juice (80\%:20\%)

A3-Aloe Vera Juice: Lemon Juice (60\%:40\%)

A4-Aloe Vera Juice: Lemon Juice (40\%:60\%)

A5-Aloe Vera Juice: Lemon Juice (20\%:80\%)

A6-Aloe Vera Juice: Lemon Juice (0\%:100\%)

Table.2 Effects of immersion duration on quality parameter of tofu

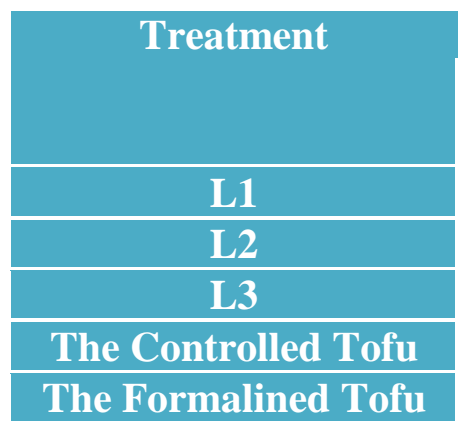

\begin{tabular}{|c|c|c|}
\hline \multicolumn{3}{|c|}{ Parameter } \\
\hline $\begin{array}{c}\text { Formalin } \\
\text { Content }(\%)\end{array}$ & $\begin{array}{c}\text { Total Microbe } \\
(\log \text { CFU/ml })\end{array}$ & Protein Content $(\%)$ \\
\hline $58.457^{\mathrm{b}}$ & $3.978^{\mathrm{c}}$ & $4.817^{\mathrm{d}}$ \\
\hline $49.892^{\mathrm{c}}$ & $4.502^{\mathrm{b}}$ & $4.968^{\mathrm{c}}$ \\
\hline $41.752^{\mathrm{d}}$ & $4.640^{\mathrm{b}}$ & $5.161^{\mathrm{b}}$ \\
\hline $0.000^{\mathrm{e}}$ & $5.552^{\mathrm{a}}$ & $6.331^{\mathrm{a}}$ \\
\hline $84.214^{\mathrm{a}}$ & $0.000^{\mathrm{d}}$ & $3.800^{\mathrm{f}}$ \\
\hline
\end{tabular}

L1-Immersion time 30 minutes

L2-Immersion time 60 minutes

L3-Immersion time 90 minutes

Table.3 Effects of storage duration on the total microbe of tofu

\begin{tabular}{cccc}
\hline Treatment & 3-Day Storage & 6-Day Storage & 9-Day Storage \\
\hline The Controlled Tofu & $6.4206^{\mathrm{a}}$ & $6.9135^{\mathrm{a}}$ & $7.1703^{\mathrm{a}}$ \\
A1L3 & $5.2987^{\mathrm{b}}$ & $5.9215^{\mathrm{b}}$ & $6.2208^{\mathrm{b}}$ \\
The Formalined Tofu & $3.8819^{\mathrm{c}}$ & $4.6910^{\mathrm{c}}$ & $5.7864^{\mathrm{c}}$ \\
\hline
\end{tabular}

A1L3-100\% Aloe Vera Juice

With 90 minute Immersion

Duration 
Fig.1 Comparative relationship between aloe vera and lemon juice with formalin content of tofu

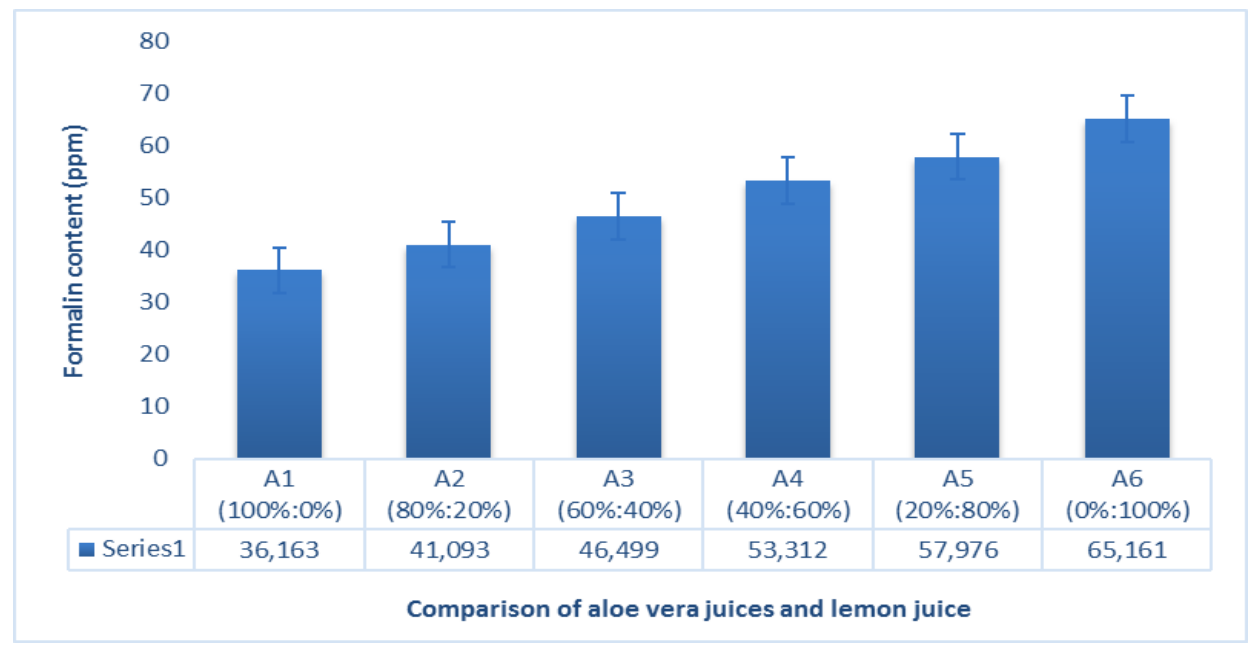

Fig.2 Immersion time relationship to the level of formaldehyde

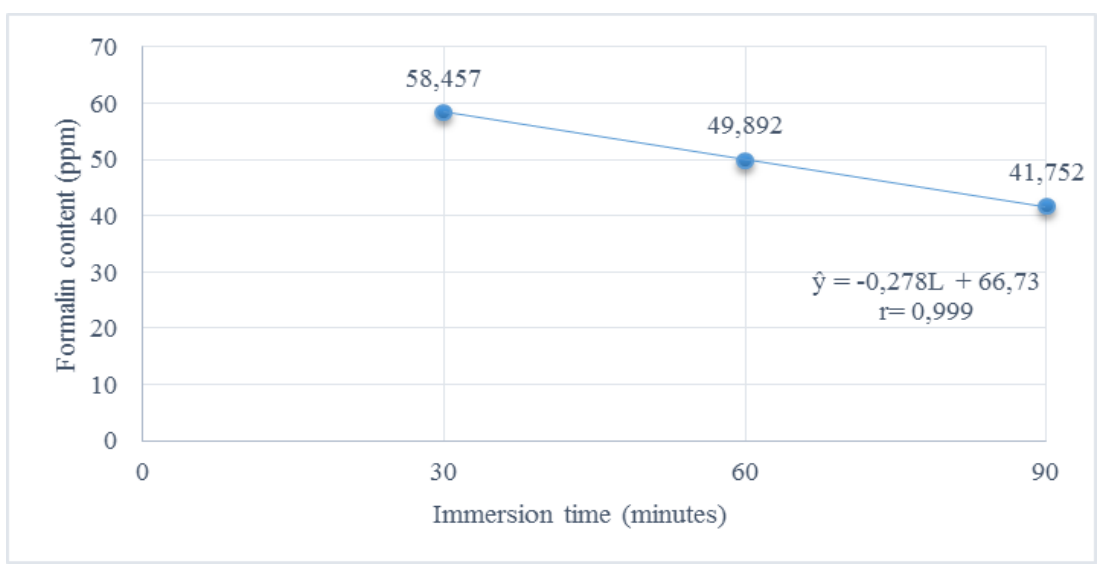

Fig.3 Comparative relationship of aloe vera and lemon juice with total microbe tofu

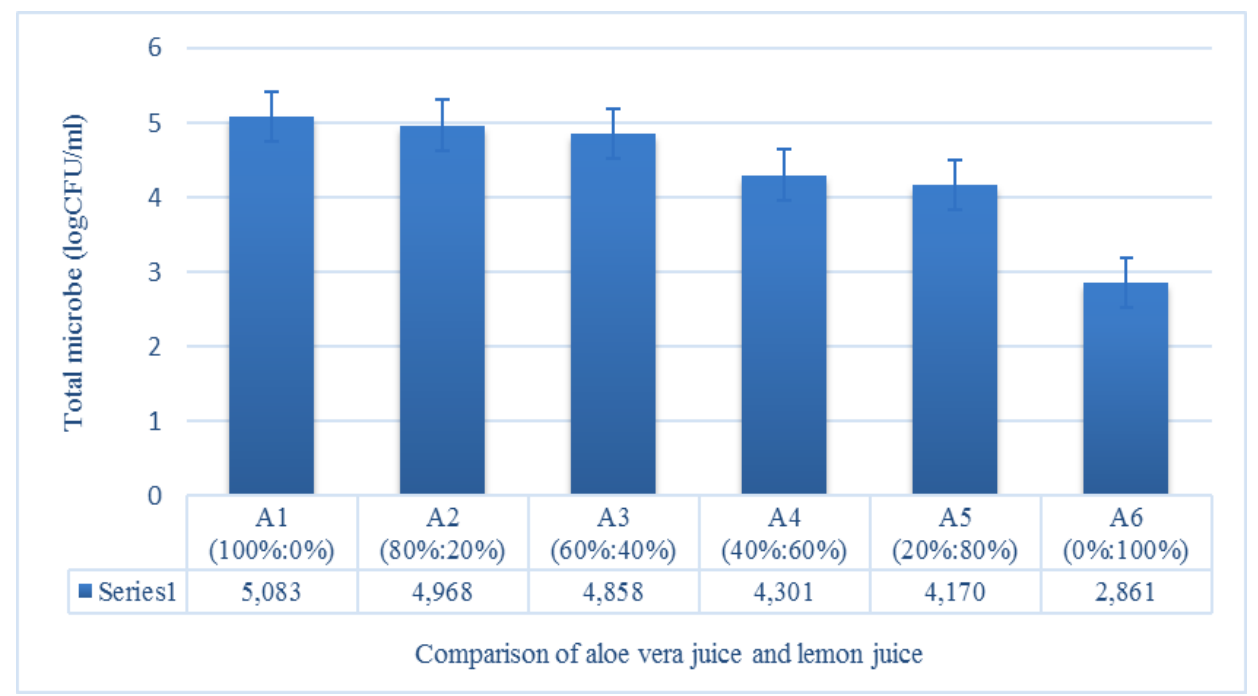


Fig.4 Immersion time relationships with total microbes tofu

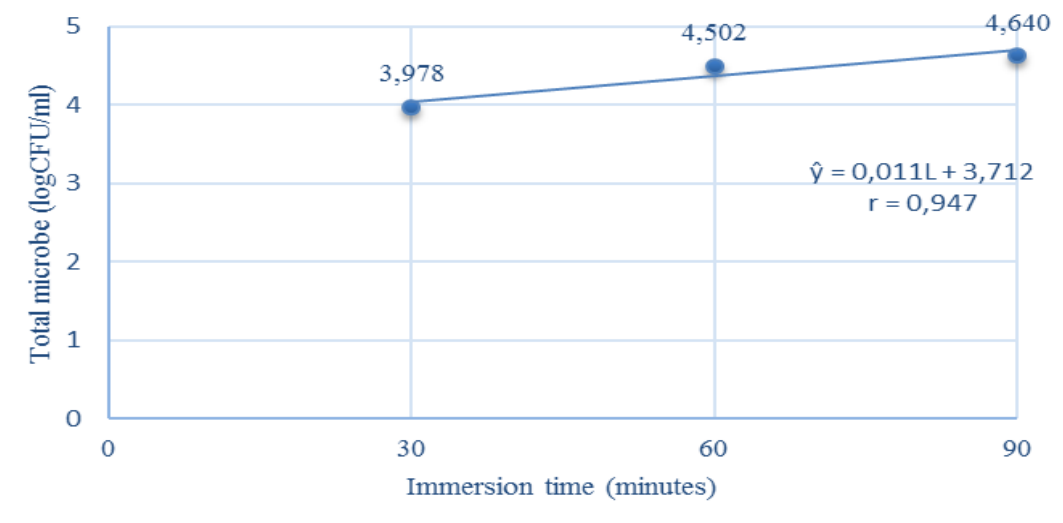

Fig.5 Comparative relationship between of aloe vera and lemon juice with protein content tofu

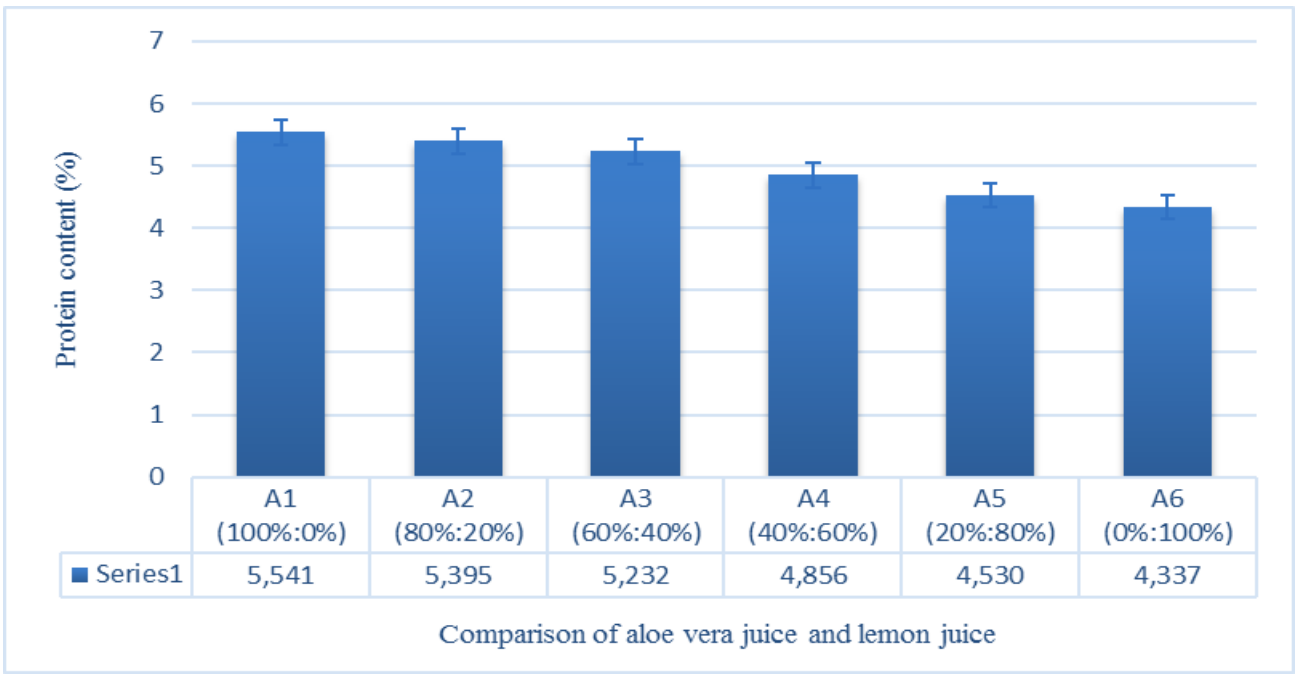

Fig.6 Immersion time relationship with protein content tofu

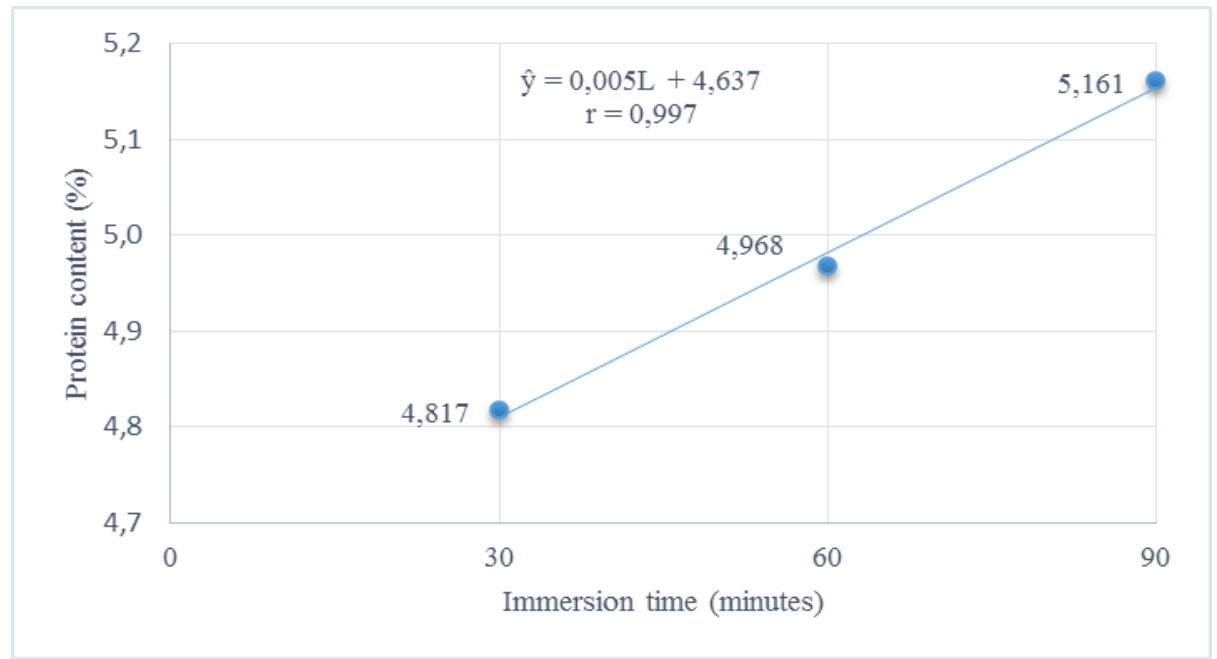


Fig.7 The reaction of formalin and protein (Thavarajah et al., 2012)

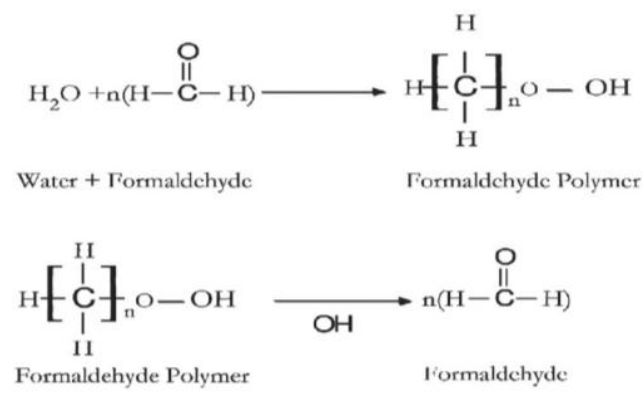

Wirawan et al., (2017) ascertained that saponin in the casava leaves could reduce the formalin content of white shrimp. Rosida (2002) observed that the saponin content in the aloe vera was $500 \mu \mathrm{g} / \mathrm{ml}$.

Saponin contained in aloe vera reduces the formalin content in tofu through saponification reaction. The sulfactant substances in saponin are amphatic as well as possess non-polar hydrophonic and polar hydropholic which can form water and formalin emulsion so that saponin acts as an emulator. The saponin compound is adsorbed into the inter-phase areas and binds the formaldehyde particles to obtain the emulsion stability of polar group. After the formaldehyde particles are bound to the saponin compound, saponin will dissolve and form micelles. The part of micelles can interact with water and formalin so that the formaldehyde can dissolve together with water (Dwimayasanti, et al., 2014).

\section{Total Microbe}

Table 1 reveals that in the formalined tofu, the total microbe is $0.00 \log \mathrm{CFU} / \mathrm{ml}$. Formalin can prevent food from the damage due to microbes. Formalin has capability to inhibit the growth of aerobic microbes at the very low concentration.

Table 2 shows that tofu with the treatment of soaking in the aloe vera and lemon juice was discovered that the fewest microbes were found in the A6 treatment with 30-minute immersion. Because the formalin content in the sample was still high, formalin was still able to inhibit the growth of microbes. Ramesh, et al., (2017) showed that the 10\% formalin could be grown by CoNS and E. coli microbes. Anaerobic bacteria, however, are generally less susceptible to formalin because of their complex cell walls.

The highest microbial count was obtained in the treatment of A1 (100\%:0\%) with 90minute soaking time. the longer the immersion of tofu in the juice of aloe vera then the total microbial is increasing (Fig. 3 and Fig. 4). The high number of microbes was caused by the large amount of formalin decomposed by the compounds contained in the aloe vera so that crosslinking between protein and formalin released. The release of the crosslink resulted in the high content of protein that could be used by microbes as substrates for their growth. According to Hershey and Chase (2007), protein and nucleic acid were excellent mediums for microorganism.

\section{Protein content}

Table 1 exhibits that at the treatment of the controlled tofu, the protein content decreased from $6.31 \%$ to $3.80 \%$ after formalin compounds were given. Decreasing the protein content took place due to the protein 
damages by the formalin compounds. The formalin reactivity could cause cross-linking with protein in which the formaldehyde reacted with amino N-terminal and cysteine side chains, histidine, lysine, tryptophan, and arginine (Hoffman, et al., 2015) causing the formation of methylene compound $\left(-\mathrm{CH}_{2}\right)$.

After soaking the formalin tofu with several concentrations of aloe vera and lemon juices, it was identified that an increase of protein content in the tofu occurs. The highest increase attained in the A1 (100\%:0\%) treatment of the protein content was at $5.541 \%$ and the lowest increase was in the A6 (0\%:100\%) treatment of the protein content at $4.337 \%$. This matter occurred due to a decrease of formalin content in tofu after soaking in aloe vera and lemon juices. The decrease of formalin level caused a breakdown of crosslink between protein and formalin that formed methylene so that the protein structure returned to its original state the protein content in tofu increased.

Methylene compounds could decompose through hydrolysis reactions to form protein and formalin (Purawisastra and Sahara, 2011). The formalin and protein reactions can be noticed in Figure 7.

\section{Total microbes during storage}

The best treatment was the treatment with capability of decreasing the highest formalin content in the treatment of A1 (100\% aloe vera juice). The influence of storage duration on total microbial tofu can be seen in Table 3 .

During 3-day storage, it was discovered that in the formalin tofu, the microbial growth was found. In the subsequent storage, the number of microbes increased. During the storage period, formalin degraded so that the formalin content became decreased. The low content of formalin allowed the microbes to grow though the tofu still contained formalin. Anaerobic bacteria were generally susceptible to formalin because of their complex cell walls, where the outer membranes acted as permeability barrier in limiting or preventing the entry of many chemical substances.

In this study the effectiveness of the aloe vera and lemon juices was obtained by comparing their concentrations. Regarding the result of the research, it was revealed that the $100 \%$ aloe vera juice could reduce the formalin level by $57.05 \%$ from the previous formalin content $84.214 \mathrm{mg} / \mathrm{kg}$ to $36.163 \mathrm{mg} / \mathrm{kg}$ and the lowest protein content was obtained as well at approximately $12.48 \%$. The amount of formalin decomposed by saponin compounds contained in the aloe vera led to the crosslinking between protein formalin released due to the role of saponin as an emulator. With respect to the microbial growth and the immersion period, it was discovered that the longer soaking time occurred, the more total microbe increased. Further studies are therefore necessary to be conducted by adding the immersion duration and observing the effects of aloe vera juice on the decrease of formaldehyde in the boiled, steamed, and fried tofu.

\section{Acknowledgement}

The present writer would like to thank to the University of Andalas for the provided facilities in analysing the formalin content by utilizing HPLC. In addition, a great gratitude is also expressed to the Food Science Departmentof the Agriculture Faculty at University of Sumatera Utara for the facilities to analyse the protein content and the total of microbes.

\section{References}

Ali, A. M., Devi, L. I., Nayan, V., Chanu, K. H. V. and Ralte, L. 2010. Antioxidant Activity of Fruits Available In Aizawl Market of Mizoram, India. International Journal of Biological and Pharmaceutical, 1(2):76-81.

Food and Drug Supervisory Agency (BPOM). 2017. Press Release Healthy Living Foods Movement Conscious Food Safety Movement towards Safe Food Indonesia. http://www.pom.go.id. Retrieved 23 
November 2017.

Damayanti, E., Ma'ruf, W.F., and Wijayanti, I. 2014. Effectiveness of Turmeric (Curcuma lunga Linn) as Formalin Reducer on White Shrimp (Penaeus merguensis) Storage of cold temperatures. Journal of Fishery Products Processing and Biotechnology. 3 (1): $98-107$

Gusviputri, A., Meliana, N. P. S., Aylianawati, and Indraswati, S. 2013. Soap Making with Aloe Vera as Natural Antiseptic, Widya Technique, 12 (1): 11-21.

Hershey, A. D., and Chase, M. 2017. Independent Functions of Viral Protein and Nucleic Acid in Growth of Bacteriophage. Bayern Munchen: Springer.

Hoffman, E. A., Frey, B. L., Smith, L. M., and Auble, D. T. 2015. Formaldehyde Crosslinking: A Tool for the Study of Chromatin Complexes. Journal Biology Chemical. 290(44):26404-26411.

Jannah, M., Ma'ruf, W. F., and Surti, T. 2014. Galangal Health as Reducing Formalin Levels in White Shrimp During Cold Storage. J. processing and Biotech. Fishery Products, (3)1:70-79.

Jooyandeh, H. 2011. Soy Products as Healthy and Functional Foods. Journal of Scientific Research, 7(1):71-80.

Li J., Zhu J and Ye L. 2007. Determination of Formaldehyde in Squid by High Performance Liquid Chromatography. Asia Pac. J. Clin. Nutr., 16(1): 127-130.

Purawisastra, S and Sahara, E. 2011. Formalin Absorption by Several Food Types and Its Removal through Immersion in Hot
Water. Journal of Nutrition and Food Research. 34 (1).

Ramesh, G. A., Katiyar, R., Sujatha, A., Raj, B., Gupta, and Kumar, A., 2017. Detection of Microorganisms on Formalin-Fixed and Stored Pathology Tissues: $A$ Microbiology Study Journal of Oral and Maxillofacial Pathology. 21(1):64

Rosida, J. 2002. Saponin Test in Aloe Vera, Noni Fruit Waste and Neem Leaf. Laboratory Research Papers. Nontechnical Research Functional Meeting. Ciawi Livestock Hall. Bogor. 75.

Shita, A. E., 2016. Selectivity of Formalin Analysis Methods by Spektrofotometri with Schiff's Reagents. Essay. Yogyakarta: Yogyakarta State University.

Thavarajah, R., Mudimbaimannar, V. K., Elizabeth, J., Rao, U. K., and Ranganathan, K., 2012. Chemical and Physical Basics of Routine Formaldehyde Fixation. Journal of Oral and Maxillofacial Pathology. 16(3): 400-405.

Wikanta, W. 2011. Effect of Starfruit and Boiling Addition on Formalin Residues and Protein Profile of White Shrimp Formalin and Its Use as a Source of Nutrition Education and Food Safety to the Community, Postgraduate of FK UB, Surabaya.

Wirawan, Tantalu, L., and Suliana, G., 2017. Effectiveness of Cassava Leaf (Manihot esculenta) Var. Malang 1 as Reducer of Formalin Level on White Shrimp (Pennaeus vannamei). Research Journal of Applied Agriculture. 17(3):170-175.

\section{How to cite this article:}

Daniela, C., H. Rusmarilin and Sinaga, H. 2018. Effectiveness of Aloe Vera and Lemon Juices Concentration in Reducing Formalin Content in Tofu Sumedang. Int.J.Curr.Microbiol.App.Sci. 7(04): 1316-1326. doi: https://doi.org/10.20546/ijcmas.2018.704.147 